\title{
Modified-atmosphere Packaging of Blueberry Fruit: Modeling Respiration and Package Oxygen Partial Pressures as a Function of Temperature
}

\author{
Arthur C. Cameron, Randolph M. Beaudry, Nigel H. Banks', and Mark V. Yelanich \\ Department of Horticulture, Michigan State University, East Lansing, MI 48824-1325
}

Additional index words. activation energy, anaerobiosis, film permeability, RQ breakpoint, Vaccinium corymbosum

\begin{abstract}
A mathematical model was developed to characterize the interaction of fruit $\mathrm{O}_{2}$ uptake, steady-state $\mathrm{O}_{2}$ partial pressures in modified-atmosphere (MA) packages $\left(\left[\mathrm{O}_{2}\right]_{\mathrm{pkg}}\right)$, and film permeability to $\mathrm{O}_{2}\left(\mathrm{Po}_{2}\right)$ from previously published data for highbush blueberry (Vaccinium corymbosum $\mathrm{L}$. 'Bluecrop') fruit held between 0 and $25 \mathrm{C} \mathrm{O}_{2}$ uptake in nonlimiting $\mathrm{O}_{2}$ $\left(\mathrm{RO}_{2}{ }^{\text {max }, \mathrm{T}}\right)$ and the $\left[\mathrm{O}_{2}\right]_{\mathrm{pkg}}$ at which $\mathrm{O}_{2}$ uptake was half-maximal $\left(\mathrm{K}_{1 / 2}{ }^{\mathrm{T}}\right)$ were both exponentially related to temperature. The activation energy of $\mathrm{O}_{2}$ uptake was less at lower $\left[\mathrm{O}_{2}\right]_{\mathrm{pkg}}$ and temperature. The predicted activation energy for permeation of $\mathrm{O}_{2}$ through the film $\left(\mathrm{E}_{\mathrm{a}}^{\mathrm{P}_{2}}, \mathrm{~kJ} \cdot \mathrm{mol}^{-1}\right)$ required to maintain close-to-optimum $\left[\mathrm{O}_{2}\right]_{\mathrm{pkg}}$ across the range of temperatures between 0 and $25 \mathrm{C}$ was $\approx 60 \mathrm{~kJ} \cdot \mathrm{mol}^{-1}$. Packages in which diffusion was mediated through polypropylene or polyethylene would have $\mathbf{E}_{\mathrm{a}}^{\mathbf{P}_{\mathbf{O}_{2}}}$ values of $\approx 50$ and $40 \mathrm{~kJ} \cdot \mathrm{mol}^{-1}$, respectively, and would have correspondingly greater tendencies for $\left[\mathrm{O}_{2}\right]_{\mathrm{pkg}}$ to decrease to excessively low levels with an increase in temperature. Packages that depend on pores for permeation would have an $\mathbf{E}_{a}^{\mathbf{P}_{0_{2}}}$ of $<5 \mathrm{~kJ} \cdot \mathrm{mol}^{-1}$. Our procedure predicted that, if allowed to attain steady-state conditions, packages with pores and optimized to $2 \mathrm{kPa} \mathrm{O}_{2}$ at $0 \mathrm{C}$ would become anaerobic with as little as a $5 \mathrm{C}$ increase in temperature. The results are discussed in relation to the risk of temperature abuse during handling and marketing of MA packaged fruit and strategies to avoid induction of anaerobiosis.
\end{abstract}

Shelf-life of blueberries (Vaccinium spp.) can be extended by controlled-atmosphere (CA) storage (Smittle and Miller, 1988) and modified-atmosphere (MA) packaging (Dostal-Lange et al., unpublished data). Current conditions used in CA storage for highbush blueberry range from 1.5 to $2.5 \mathrm{kpa} \mathrm{O}_{2}$ and 5 to $12 \mathrm{kPa}$ $\mathrm{CO}_{2}$ at $0 \mathrm{C}\left(1 \% \mathrm{O}_{2}=1.013 \mathrm{kpa} \mathrm{O}_{2}\right.$ at sea level). MA packaging has the potential to provide low $\mathrm{O}_{2} /$ high $\mathrm{CO}_{2}$ regimes similar to $\mathrm{CA}$ storage. The traditional approach for designing an MA package is to generate a physiologically effective package $\mathrm{O}_{2}$ partial pressure $\left(\left[\mathrm{O}_{2}\right] \mathrm{pkg}\right.$, kpa, see Table 1$)$ by matching total respiratory $\mathrm{O}_{2}$ uptake of the packaged product to the total $\mathrm{O}_{2}$ permeation through the film (Kader et al., 1989). Ideally, an MA package should maintain safe and effective partial pressures of $\mathrm{O}_{2}$ and $\mathrm{CO}_{2}$ over a range of temperatures because there is a distinct risk of temperature abuse during shipping, handling, and marketing. Fruits held in MA may go anaerobic if temperatures increase (Kader et al., 1989), but little has been published on the extent of this problem or possible solutions. Empirical approaches have not identified MA package designs that can cope with large increases in temperature.

Mathematical models have been used widely for predicting steady-state partial pressures of $\left[\mathrm{O}_{2}\right]_{\mathrm{pkg}}$ and $\left[\mathrm{CO}_{2}\right]_{\mathrm{pkg}}$ in MA systems (Banks et al., 1989; Cameron et al., 1989; Emend et al., 1991; Kader et al., 1989; Kok and Raghavan, 1985; Mannapperuma et al., 1989; Wade and Graham, 1987). However, the general applicability of such predictive models has been limited by lack of detailed knowledge of the relationship between the rate of $\mathrm{O}_{2}$ uptake $\left(\mathrm{Ro}_{2}, \mathrm{mmol} \cdot \mathrm{kg}^{-1} \cdot \mathrm{h}^{-1}\right)$ to $\left[\mathrm{O}_{2}\right]_{\mathrm{pkg}}$, particularly at different temperature.

Beaudry et al. (1992) have recently published data for high bush

Received for publication 11 Dec. 1992. Accepted for publication 16 June 1993. Mention of a trademark, proprietary product, or vendor does not constitute a guarantee or warranty of the product by either Michigan State Univ. or Massey Univ. and does not imply its approval to the exclusion of other products or vendors that also may be suitable. The cost of publishing this paper was defrayed in part by the payment of page charges. Under postal regulations, this paper therefore must be hereby marked advertisement solely to indicate this fact.

'Dept. of Plant Science, Massey Univ., Palmerston North, New Zealand. blueberry fruit that make feasible the development of a more general model. They showed that temperature affected both the overall rate of blueberry respiration and the shape of the response curves relating $\mathrm{RO}_{2}$ to $\left[\mathrm{O}_{2}\right]_{\mathrm{pkg}}$ at steady-state. They also observed that $\left[\mathrm{O}_{2}\right]_{\mathrm{pkg}}$ within low-density polyethylene (LDPE) packages containing the same mass of blueberries decreased with increasing temperature and vice versa. This result inferred that the activation energy of film $\mathrm{O}_{2}$ permeation $\left(\mathrm{E}_{\mathrm{a}}^{\mathrm{P}_{2}}, \mathrm{~kJ} \cdot \mathrm{mol}^{-1}\right)$ was less than the activation energy of fruit $\mathrm{R}_{\mathrm{O}_{1}}\left(\mathrm{E}_{\mathrm{a}}^{\mathrm{R} \mathrm{O}_{2}}\right)$. Risk of anaerobiosis within LDPE packages was further enhanced by the observation that the critical $\left[\mathrm{O}_{2}\right]_{\mathrm{pkg}}$ at which anaerobic respiration was induced increased with temperature (Beaudry et al., 1992). For instance, at $0 \mathrm{C}$, the fruit tolerated down to $\approx 1.8 \mathrm{kPa} \mathrm{O}_{2}$, whereas, at $25 \mathrm{C}$, they required $\approx 4.0 \mathrm{kPa} \mathrm{O}_{2}$ to avoid an elevated respiratory quotient (RQ) (Beaudry et al., 1992). Thus, choosing a film with an $\mathrm{E}_{\mathrm{a}}^{\mathrm{PO}_{2}}$ that exactly matches would not be enough to ensure that a package optimized at low temperature would maintain an ideal $\left[\mathrm{O}_{2}\right]_{\mathrm{pkg}}$ over the $25 \mathrm{C}$ temperature range. While values for $\mathrm{E}_{\mathrm{a}}^{\mathrm{PO}_{2}}$ are known for some films (Beaudry et al., 1992; Pauly, 1989), values of $E_{a}^{R^{2}}$ are not available for fruit maintained at different levels of $\left[\mathrm{O}_{2}\right]$.

In this paper, we set out to develop a model for prediction of steady-state $\left[\mathrm{O}_{2}\right]_{\mathrm{pkg}}$ for MA packages of blueberries at temperatures between 0 and $25 \mathrm{C}$ based on the data of Beaudry et al. (1992). The model was used to predict MA systems that might provide suitable levels of $\left[\mathrm{O}_{2}\right]_{\mathrm{pkg}}$ over a wide range of temperatures.

\section{Model Description}

For a package in which gas exchange is at steady-state, $\mathrm{O}_{2}$ flux into the package $\left(\mathrm{FO}_{2}, \mathrm{mmol} \cdot \mathrm{h}^{-1}\right)$ can be calculated from

$$
\mathrm{F}_{\mathrm{O}_{2}}=\frac{\mathrm{P}_{\mathrm{O}_{2}} \mathrm{~A}}{\Delta \mathrm{x}}\left(\left[\mathrm{O}_{2}\right]_{\mathrm{arm}}-\left[\mathrm{O}_{2}\right]_{\mathrm{pkg}}\right)
$$

Abbreviations: MA, modified atmosphere; LDPE, low-density polyethylene; RQ, respiratory quotient. 
Table 1. Description of variables.

\begin{tabular}{|c|c|}
\hline Variable & Description and units \\
\hline A & Surface area of polymer, $\mathrm{cm}^{2}$ \\
\hline $\mathrm{Ar}$ & Arrhenius constant \\
\hline$\left[\mathrm{CO}_{2}\right]_{\mathrm{pkg}}$ & Package partial pressure of $\mathrm{CO}_{2}, \mathrm{kPa}$ \\
\hline $\mathrm{E}_{\mathrm{a}}^{\mathrm{P}_{2}}$ & Activation energy of polymer $\mathrm{O}_{2}$ permeation, $\mathrm{kJ} \cdot \mathrm{mol}^{-1}$ \\
\hline $\mathrm{E}_{\mathrm{a}}^{\mathrm{R}} \mathrm{O}_{2}$ & Activation energy of $\mathrm{O}_{2}$ uptake by fruit, $\mathrm{kJ} \cdot \mathrm{mol}^{-1}$ \\
\hline $\mathrm{F}_{\mathrm{O}_{2}}$ & Total $\mathrm{O}_{2}$ flux through package, $\mathrm{mmol} \cdot \mathrm{h}^{-1}$ \\
\hline $\mathrm{K}_{1 / 2}^{\mathrm{T}}$ & Michaelis-Menten constant for R., kpa \\
\hline$\left[\mathrm{O}_{2}\right]_{\mathrm{atm}}$ & Partial pressure of $\mathrm{O}_{2}$ outside of package, $\mathrm{kPa}$ \\
\hline$\left[\mathrm{O}_{2}\right]_{\mathrm{pkg}}$ & Package partial pressure of $\mathrm{O}_{2}, \mathrm{kPa}$ \\
\hline $\mathrm{P}_{\mathrm{O}_{2}}$ & $\begin{array}{l}\text { Polymer } \mathrm{O}_{2} \text { permeability coefficient, } \mathrm{mmol} \cdot \mathrm{cm}^{-1} \cdot \mathrm{cm}^{-2} \text { per h per } \\
\mathrm{kPa}\end{array}$ \\
\hline $\mathrm{R}_{\mathrm{O}_{2}}$ & $\mathrm{O}_{2}$ uptake of fruit per unit weight, $\mathrm{mmol} \cdot \mathrm{kg}^{-1} \cdot \mathrm{h}^{-1}$ \\
\hline $\mathrm{R}_{\mathrm{O}_{2}}^{\max , \mathrm{T}}$ & Maximum $\mathrm{RO}_{2}$ as a function of $\mathrm{T}, \mathrm{mmol} \cdot \mathrm{kg}^{-1} \cdot \mathrm{h}^{-1}$ \\
\hline $\mathrm{R}_{\mathrm{O}_{2}}^{\text {total }}$ & Total $\mathrm{O}_{2}$ uptake of packaged fruit, $\mathrm{mmol} \cdot \mathrm{h}^{-1}$ \\
\hline $\mathrm{T}$ & Temperature, ${ }^{\circ} \mathrm{C}$ \\
\hline W & Weight of packaged fruit, $\mathrm{kg}$ \\
\hline$\Delta \mathrm{x}$ & Thickness of polymer, $\mathrm{cm}$ \\
\hline
\end{tabular}

where $\mathrm{PO}_{2}$ is the polymer $\mathrm{O}_{2}$ permeability $\left(\mathrm{mmol} \cdot \mathrm{cm}^{-1} \cdot \mathrm{cm}^{-2}\right.$ per $\mathrm{h}$ per $\mathrm{kPa}), \mathrm{A}$ is the polymer surface area $\left(\mathrm{cm}^{2}\right), \Delta \mathrm{x}$ is the polymer thickness $(\mathrm{cm})$, and $\left[\mathrm{O}_{2}\right]_{\mathrm{atm}}$ is the partial pressure of $\mathrm{O}_{2}$ in the atmosphere outside the package $(\mathrm{kPa})$. The total $\mathrm{O}_{2}$ uptake: $\left(\mathrm{R}_{\mathrm{O}}^{\text {total }}\right.$, $\left.\mathrm{mmol} \cdot \mathrm{h}^{-1}\right)$ of the packaged fruit can be modeled as a MichaelisMenten function of $\left[\mathrm{O}_{2}\right]_{\mathrm{pkg}}$ (Lee et al., 1991):

$$
\mathrm{R}_{\mathrm{O}_{2}}^{\text {total }}=\mathrm{R}_{\mathrm{O}_{2}} \cdot \mathrm{W}=\mathrm{R}_{\mathrm{O}_{2}}^{\mathrm{max}, \mathrm{T}} \frac{\left[\mathrm{O}_{2}\right]_{\mathrm{pkg}}}{\left(\mathrm{K}_{1 / 2}^{\mathrm{T}}+\left[\mathrm{O}_{2}\right]_{\mathrm{pkg}}\right)} \cdot \mathrm{W}
$$

where $\mathrm{W}$ is fruit weight $(\mathrm{kg}) . \mathrm{K}_{1 / 2}{ }^{\mathrm{T}}(\mathrm{kPa})$ can be considered the apparent $\mathrm{K}_{1 / 2}$ of $\mathrm{Ro}_{2}$ for the entire fruit, at temperature $\mathrm{T}\left({ }^{\circ} \mathrm{C}\right)$ and thus incorporates effects of variability in skin and flesh resistance to gas diffusion in combination with changes in respiratory flux associated with fruit temperature. $\mathrm{R}_{\mathrm{O}}^{\max , \mathrm{T}}\left(\mathrm{mmol} \cdot \mathrm{kg}^{-1} \cdot \mathrm{h}^{-1}\right)$ is the theoretical maximum rate of $\mathrm{RO}_{2}$ at each temperature. Based on unpublished results (see Beaudry et al., 1992), we assumed $\left[\mathrm{CO}_{2}\right]_{\mathrm{pkg}}$ had no effect on $\mathrm{Ro}_{2}$. $\mathrm{T}$ :

Both $\mathrm{R}_{\mathrm{O}_{2}}^{\text {max. }}$, and $\mathrm{K}_{1 / 2}{ }^{\mathrm{T}}$ were modeled as exponential functions of

$$
\begin{aligned}
& R_{\mathrm{O}_{2}}^{\max , \mathrm{T}}=\mathrm{a} \cdot \mathrm{e}^{\mathrm{b} \cdot \mathrm{T}}+\mathrm{c} \\
& \mathrm{K}_{\mathrm{I} / 2}^{\mathrm{T}}=\mathrm{q} \cdot \mathrm{e}^{\mathrm{r} \cdot \mathrm{T}}+\mathrm{s}
\end{aligned}
$$

Substituting Eqs. [3 and 4] into Eq. [2] yielded

$$
\mathrm{R}_{\mathrm{O}_{2}}=\frac{\left(\mathrm{a} \cdot \mathrm{e}^{\mathrm{b} \cdot \mathrm{T}}+\mathrm{c}\right) \cdot\left[\mathrm{O}_{2}\right]_{\mathrm{pkg}}}{\left(\mathrm{q} \cdot \mathrm{e}^{\mathrm{r} \cdot \mathrm{T}}+\mathrm{s}\right)+\left[\mathrm{O}_{2}\right]_{\mathrm{pkg}}}
$$

A nonlinear regression analysis using the entire data set from Beaudry et al. (1992) was performed (SAS Institute, Cary, N. C.) to estimate values for $\mathrm{a}, \mathrm{b}, \mathrm{c}, \mathrm{q}, \mathrm{r}$, ands. In the first run, the estimates of $\mathrm{c}$ and $\mathrm{s}$ were not significantly different from zero, so the nonlinear regression was repeated on a simplified model in which $\mathrm{c}$ and s were eliminated:

$$
\mathrm{R}_{\mathrm{O}_{2}}=\frac{\left(\mathrm{a} \cdot \mathrm{e}^{\mathrm{b} \cdot \mathrm{T}}\right)\left[\mathrm{O}_{2}\right]_{\mathrm{pkg}}}{\left(\mathrm{q} \cdot \mathrm{e}^{\mathrm{r} \cdot \mathrm{T}}\right)+\left[\mathrm{O}_{2}\right]_{\mathrm{pkg}}}
$$

Predicted relationships between variables were calculated from the fitted parameter values and either temperature or $\left[\mathrm{O}_{2}\right]_{\mathrm{pkg}}$. Fitted curves for $\mathrm{RO}_{2}$ at different combinations of $\left[\mathrm{O}_{2}\right]_{\mathrm{pkg}}$ and $\mathrm{T}$ were constructed using direct substitution of the values obtained for a, $\mathrm{b}, \mathrm{q}$, and $\mathrm{r}$ into Eq. [6]. The model predictions were used to generate Arrhenius plots $\left[\ln \left(\mathrm{RO}_{2}\right)\right.$ against the inverse of temperature (Kelvin)]

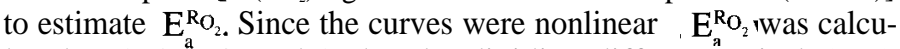
lated at $1,2,4,8$, and $16 \mathrm{kpa}$ by dividing differences in $\ln \left(\mathrm{RO}_{2}\right)$ between adjacent pairs of data points by differences in the inverse of absolute temperature (Kelvin) at $0.25 \mathrm{C}$ intervals between 0 and $25 \mathrm{C}$ (i.e., numerical differentiation of the Arrhenius plot at $0.25 \mathrm{C}$ intervals).

At steady-state, $\mathrm{FO}_{2}$ is considered to be equal to $\mathrm{R}_{\mathrm{O}_{2}}^{\text {total }}$. Combining Eqs. [1] and [2] yields.

$$
\frac{\mathrm{P}_{\mathrm{O}_{2}} \cdot \mathrm{A}}{\Delta \mathrm{x}}\left(\left[\mathrm{O}_{2}\right]_{\mathrm{atm}}-\left[\mathrm{O}_{2}\right]_{\mathrm{pkg}}\right)=\frac{\mathrm{R}_{\mathrm{O}_{2}}^{\mathrm{max}, \mathrm{T}}\left[\mathrm{O}_{2}\right]_{\mathrm{pkg}}}{\left(\mathrm{K}_{1 / 2}^{\mathrm{T}}+\left[\mathrm{O}_{2}\right]_{\mathrm{pkg}}\right)} \mathrm{W}
$$

which can be solved for $\left[\mathrm{O}_{2}\right]_{\mathrm{pkg}}$

$$
\left[\mathrm{O}_{2}\right]_{\mathrm{pkg}}=\frac{-\left(\mathrm{K}_{\mathrm{l} / 2}^{\mathrm{T}}+\mathrm{W} \cdot \frac{\Delta \mathrm{x}}{\mathrm{P}_{\mathrm{O}_{2}} \cdot \mathrm{A}} \cdot \mathrm{R}_{\mathrm{O}_{2}}^{\max , \mathrm{T}}-\left[\mathrm{O}_{2}\right]_{\mathrm{atm}}\right)}{2}+
$$

$$
\frac{\sqrt{\left(\mathrm{K}_{1 / 2}^{\mathrm{T}}+\mathrm{W} \cdot \frac{\Delta \mathrm{x}}{\mathrm{P}_{\mathrm{O}_{2}} \cdot \mathrm{A}} \cdot \mathrm{R}_{\mathrm{O}_{2}}^{\max , \mathrm{T}}-\left[\mathrm{O}_{2}\right]_{\mathrm{atm}}\right)^{2}+4 \cdot\left[\mathrm{O}_{2}\right]_{\mathrm{atm}} \cdot \mathrm{K}_{1 / 2}^{\mathrm{T}}}}{2}
$$

or for $\mathrm{P}_{\mathrm{O}_{2}} \cdot \mathrm{A} \cdot \Delta \mathrm{x}^{-1}$ :

$$
\frac{\mathrm{P}_{\mathrm{O}_{2}} \mathrm{~A}}{\Delta \mathrm{x}}=\frac{\mathrm{R}_{\mathrm{O}_{2}}^{\max , \mathrm{T}}\left[\mathrm{O}_{2}\right]_{\mathrm{pkg}} \mathrm{W}}{\left(\mathrm{K}_{1 / 2}^{\mathrm{T}}+\left[\mathrm{O}_{2}\right]_{\mathrm{pkg}}\right) \cdot\left(\left[\mathrm{O}_{2}\right]_{\mathrm{atm}}-\left[\mathrm{O}_{2}\right]_{\mathrm{pkg}}\right)}
$$

Substitution of Eqs. [3] and [4] into Eq. [7] permitted prediction of steady-state values for $\left[\mathrm{O}_{2}\right]_{\mathrm{pkg}}$ for packages with varying $\mathrm{E}^{\mathrm{PO}_{2}}$ optimized for an initial $\left[\mathrm{O}_{2}\right]_{\mathrm{pkg}}$ of either $2 \mathrm{kPa}$ at $0 \mathrm{C}$ or $4 \mathrm{kPa}$ at $25^{\mathrm{a}} \mathrm{C}$, using calculated values for permeability. We assumed that film permeability changed with temperature in a manner consistent with the Arrhenius equation (Beaudry et al., 1992; Pauly, 1989):

$$
\text { Rate }=A r \cdot e^{\frac{E_{a}}{R \cdot K}}
$$

where Ат is the Arrhenius constant and $\mathrm{K}$ the temperature in Kelvin.

Substitution of Eqs. [3] and [4] into Eq. [8] yielded predicted values for total package permeability.

All substitutions and predictions were performed using standard Quattro Pro (Version 4.1, Borland, Scotts Valley, Calif.) spreadsheets. Data were transferred to SigmaPlot for final graphical presentation.

\section{Results}

Variation in R. of blueberries with $\left[\mathrm{O}_{2}\right]_{\mathrm{pkg}}$ and $\mathrm{T}$ measured by Beaudry et al. (1992) was well-described by Eq. [6] (Fig. $1 ; r^{2}=$ 


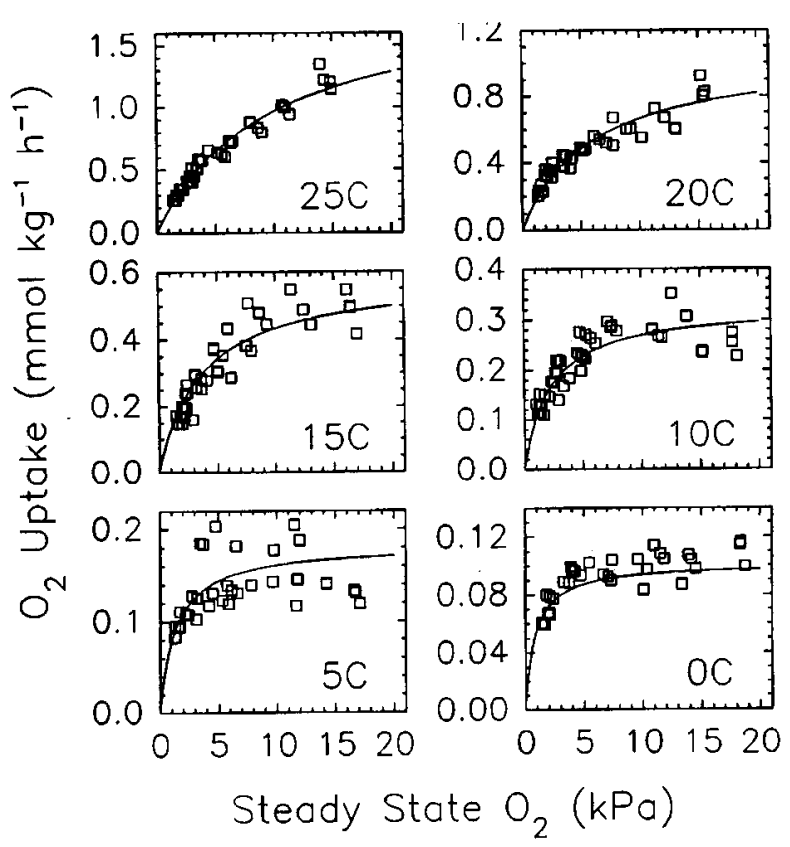

Fig. 1. Interdependent effects of steady state $\mathrm{O}_{2}$ partial pressure and storage temperature on the rate of $\mathrm{O}_{2}$ uptake of blueberry fruit in sealed LDPE packages. Data taken from Beaudry et al. (1992). Curves are predicted with the best-fit model with appropriate substitutions of $\mathrm{O}_{2}$ and temperature (Eq. [6]).

0.990 for the entire data set). The fitted values of $a$ and $b$ (Table 2) suggested that, when $\left[\mathrm{O}_{2}\right]_{\mathrm{pkg}}$ is not limiting, $\mathrm{Ro}_{2}$ would increase almost 19-fold between 0 and 25C (Fig. 2A), which is equivalent to $a \mathrm{Q}_{10}$ of 3.23. Similarly, the insertion of best-fit values for $\mathrm{q}$ and $r$ (Table 2) into Eq. [4] indicated that $\mathrm{K}_{1 / 2}$ increased 12-fold between 0 and 25C (Fig. 2B).

Use of the Michaelis-Menten model (two parameters $\mathbf{R}_{\mathbf{O}}^{\max , \mathbf{T}}$ and $\mathrm{K}_{1 / 2}$ ) to describe the relationship between $\mathrm{RO}_{2}$ and $\left[\mathrm{O}_{2}\right]_{\mathrm{pkg}}$ was more economical than the three-parameter, exponential model used by Beaudry et al. (1992). In addition, $\quad R_{0}^{\max , T}$ and $K_{1 / 2}$ were consistently related to temperature, whereas the three parameters of their exponential model were poorly related to temperature. The use of the Michaelis-Menten model for respiration has been previously suggested by Lee et al. (1991). We have chosen to denote the constant by $\mathrm{K}_{1 / 2}$ rather than by $\mathrm{K}_{\mathrm{m}}$ because it is not a true Michaelis-Menten constant.

Temperature dependence of $\mathrm{Ro}_{2}$ increased substantially when

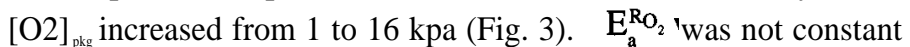
with temperature. With $\left[\mathrm{O}_{2}\right]_{\mathrm{pkg}}$ at $16 \mathrm{kPa}$, the Arrhenius plot for $\mathrm{RO}_{2}$ was essentially linear (Fig. $4 \mathrm{~A}$ ) and $\mathrm{E}_{2}^{\mathrm{R}_{2}} \mathrm{O}_{21}$ dropped only slightly with increasing temperature (Fig. 4B). At lower $\left[\mathrm{O}_{2}\right]_{\mathrm{pkg}}$ levels, Arrhenius plots for $\mathrm{Ro}_{2}$ became progressively more curvilinear, with a concomitant decline in $\mathrm{E}^{\mathrm{R}_{\mathrm{O}_{2}}}$ at elevated temperatures.

According to Eq. [3], the increase in package permeability per kilogram of fruit required to maintain a given level of $\left[\mathrm{O}_{2}\right]_{\mathrm{pkg}}$ would be $\approx 2.4$ times between 0 and $25 \mathrm{C}$ for $1 \mathrm{Wa} \mathrm{O}_{2}$ and 7.4 times for 5 $\mathrm{kpa}$ (Fig. 3) to compensate for the increase in $\mathrm{Ro}_{2}$. Permeation of

Table 2. Estimates of parameters in Eq. [5] obtained by nonlinear regression for blueberry fruit $\left[\mathrm{O}_{2}\right]$ uptake of Beaudry et al. (1992); $\mathrm{n}=288$.

\begin{tabular}{lcc}
\hline \hline Parameter & Estimate & SE \\
\hline a & 0.101 & 0.0058 \\
b & 0.117 & 0.0030 \\
q & 0.810 & 0.1290 \\
r & 0.099 & 0.00722 \\
\hline
\end{tabular}
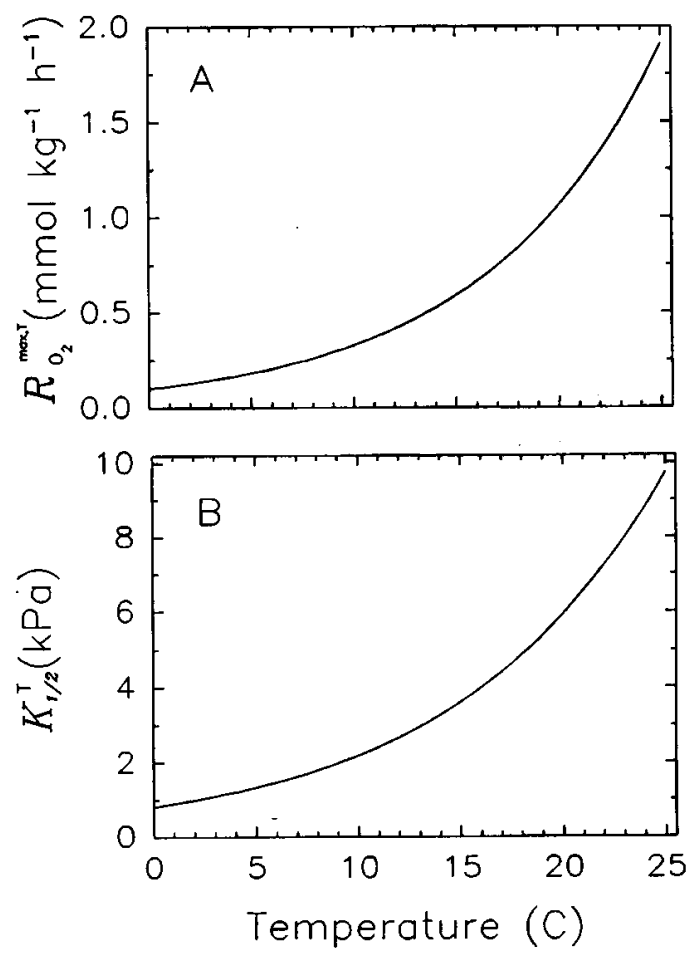

Fig. 2. Effect of temperature on predicted values for $\mathrm{RO}_{2}^{\max , \mathrm{T}}(\mathbf{A})$ and $\mathrm{K}(\mathbf{B})$ using Eqs. [3] and [4], respectively, with values for $\mathrm{a}, \mathrm{b}, \mathrm{q}$, and $\mathrm{r}$ as given in Table 2 .

gases through most polymers is known to conform to Arrhenius theory, unless there is a change of state (Pauly, 1989). The degree to which relative permeability increases in response to temperature is associated with its $\mathrm{E}_{\mathrm{a}}$ (Fig. 5). Maintaining constant levels of $\left[\mathrm{O}_{2}\right]_{\mathrm{pkg}}$ in two blueberry packages, one containing $0.5 \mathrm{kpa} \mathrm{O}_{2}$ and

Table 3. Predicted whole-package $\mathrm{O}_{2}$ permeabilities $\left(\mathrm{PO}_{2} \cdot \mathrm{A} \cdot \Delta \mathrm{x}^{-1}\right)$ required to maintain selected package partial pressures of $\mathrm{O}_{2}\left(\left[\mathrm{O}_{2}\right]_{\mathrm{pkg}}\right)$ at different temperatures (calculated using Eq. [8] and based on the $\mathrm{O}_{2}$ uptake of $1 \mathrm{~kg}$ of blueberries). Values can be adjusted for packaging any quantity of fruit by multiplication with fruit weight. $\mathrm{PO}_{2}$ can be estimated by substitution of desired surface area $\left(\mathrm{A}, \mathrm{cm}^{2}\right)$ and film thickness $(\Delta \mathrm{x}, \mathrm{cm})$. Underlined permeabilities denote the lower $\mathrm{O}_{2}$ tolerated by blueberries at each temperature before induction of anaerobic metabolism (from Beaudry et al., 1992).

\begin{tabular}{lcccccc}
\hline \hline & \multicolumn{5}{c}{$\mathrm{P}_{\mathrm{o}_{2}} \mathrm{~A} \cdot \Delta \mathrm{x}^{-1}\left(\mathrm{mmol}^{-1} \mathrm{~h}^{-1} \cdot \mathrm{kPa}^{-1}\right)$} \\
\cline { 2 - 7 } Package & \multicolumn{5}{c}{ Temp $\left({ }^{\circ} \mathrm{C}\right)$} \\
{$\left[\mathrm{O}_{2}\right](\mathrm{kPa})$} & 0 & 5 & 10 & 15 & 20 & 25 \\
\hline 1.0 & 2.83 & 3.95 & 5.19 & 6.48 & 7.75 & 8.99 \\
1.5 & 3.42 & 5.01 & 6.91 & 8.99 & 11.1 & 13.2 \\
2.0 & $\underline{7.84}$ & $\underline{5.82}$ & 8.33 & 11.2 & 14.3 & 17.3 \\
2.5 & 4.19 & 6.50 & 9.55 & 13.2 & 17.2 & 21.3 \\
3.0 & 4.49 & 7.10 & 10.7 & $\underline{15.0}$ & 20.0 & 25.3 \\
3.5 & 4.77 & 7.64 & 11.7 & 16.8 & $\underline{22.8}$ & 29.2 \\
4.0 & 5.03 & 8.15 & 12.6 & 18.5 & 25.5 & $\underline{33.1}$ \\
4.5 & 5.28 & 8.64 & 13.5 & 20.1 & 28.1 & 37.0 \\
5.0 & 5.54 & 9.12 & 14.4 & 21.7 & 30.7 & 41.0 \\
5.5 & 5.79 & 9.61 & 15.3 & 23.3 & 33.3 & 45.0 \\
6.0 & 6.05 & 10.1 & 16.2 & 24.9 & 36.1 & 49.2 \\
7.0 & 6.61 & 11.1 & 18.1 & 28.2 & 41.6 & 57.9 \\
8.0 & 7.22 & 12.2 & 20.1 & 31.8 & 47.6 & 67.3 \\
9.0 & 7.92 & 13.5 & 22.4 & 35.7 & 54.3 & 77.7 \\
10.0 & 8.73 & 15.0 & 25.0 & 40.2 & 61.7 & 89.6 \\
11.0 & 9.70 & 16.7 & 28.0 & 45.5 & 70.5 & 103 \\
12.0 & 10.9 & 18.8 & 31.7 & 51.7 & 80.9 & 120 \\
\hline & & & & & &
\end{tabular}



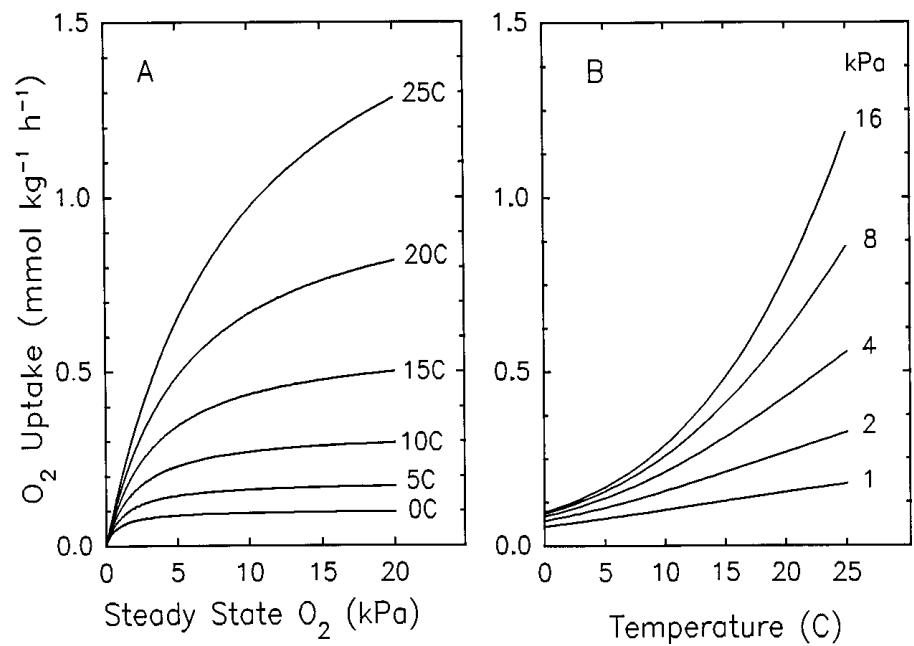

Fig. 3. Composite curves demonstrating the interdependent effects of $\left[\mathrm{O}_{2}\right]$ and temperature on the predicted rate of $\mathrm{O}_{2}$ uptake by blueberry fruit. Rates were obtained using [Eq. 5] and substituting values for a, b, q, and $\mathrm{r}$ as given in Table 2. (A) Effect of $\left[\mathrm{O}_{2}\right]$ over a range of temperatures. (B) Effect of temperature over a range of $\left[\mathrm{O}_{2}\right]$ partial pressures.

the other containing $5.0 \mathrm{kPa}$ at $0 \mathrm{C}$, would require $\mathrm{E}_{\mathrm{a}}^{\mathrm{PO}_{2} \text { values of } \approx 24}$ and $55 \mathrm{~kJ} \cdot \mathrm{mol}^{-1}$, respectively. This picture is complicated by the fact that the desired level of $\left[\mathrm{O}_{2}\right]_{\mathrm{pkg}}$ is itself a function of temperature (Beaudry et al., 1992). Thus, an ideal value for $\mathrm{E}_{\mathrm{a}}^{\mathrm{PO}_{2}}$ depends on the desired levels of $\left[\mathrm{O}_{2}\right]_{\mathrm{pkg}}$ at the range of temperatures to which the package is to be exposed as well as the crop's $\mathrm{E}_{\mathrm{a}}^{\mathrm{R}_{2}}$.

Predicted whole-package $\mathrm{O}_{2}$ permeabilities $\left(\mathrm{P}_{\mathrm{O}} \cdot \mathrm{A} \cdot \Delta \mathrm{x}^{-1}\right)$ were calculated using Eq. [8] (Table 3). Estimation of the required film permeability at each temperature for a given MA system to maintain the blueberry fruit in an aerobic condition is possible. In Table 3, the film permeability required to maintain aerobic fruit at each temperature is indicated by underlining based on the data of Beaudry et al. (1992).

Predictions of $\left[\mathrm{O}_{2}\right]_{\mathrm{pkg}}$ for packages optimized to $2 \mathrm{kPa}$ at $0 \mathrm{C}$ were constructed to determine how changing $\mathrm{E}_{\mathrm{a}}^{\mathrm{P}_{2}}$ affects the potential risk of temperature-induced anaerobiosis (Fig. 6). The change of predicted steady-state $\left[\mathrm{O}_{2}\right]_{\text {pkg }}$ for films with an $\mathrm{E}_{2}^{\mathrm{P}_{2}}$ of 60 $\mathrm{kJ} \cdot \mathrm{mol}^{-1}$ indicated that blueberries could remain aerobic throughout the entire 0 to $25 \mathrm{C}$ range. In contrast, for $\mathrm{LDPE}\left(\mathrm{E}_{\mathrm{a}}^{\mathrm{P}_{2}}=39.7\right.$ $\left.\mathrm{kJ} \cdot \mathrm{mol}^{-1}\right),\left[\mathrm{O}_{2}\right]_{\mathrm{pkg}}$ would be similar at $25 \mathrm{C}$ as at $0 \mathrm{C}$ and this would not be sufficient to avoid the risk of anaerobic induction if the packages were exposed to the higher temperatures.

For packages in which the principal route for gas diffusion was
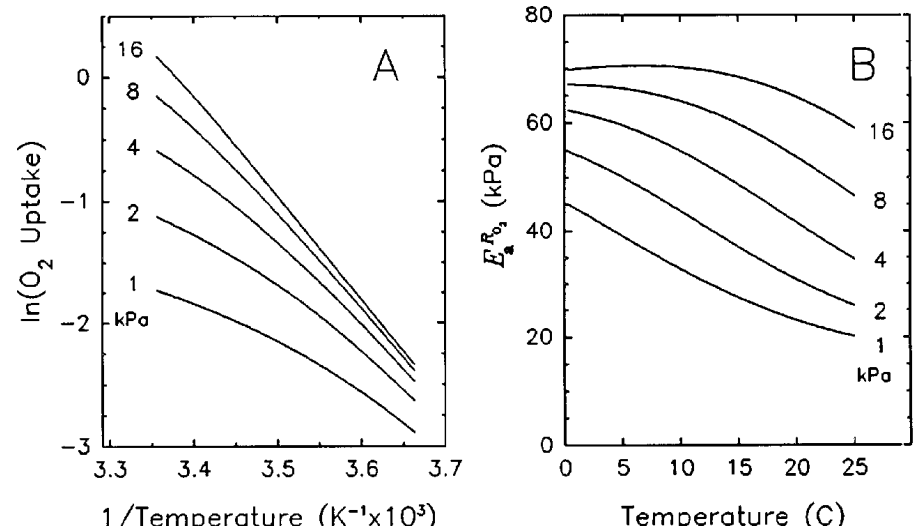

Fig. 4. Estimation of activation energy $\left(\mathrm{E}_{\mathrm{a}}\right)$ for blueberry fruit respiration. (A) Arrhenius plots for $\mathrm{O}_{2}$ uptake over a range of $\mathrm{O}_{2}$ partial pressures obtained by transformation of Eq. [5]. (B) Calculated values for $\mathrm{E}$ obtained by stepwise numerical integration of the data used in Fig. 4, left at 1, 2, 4, 8, and $16 \mathrm{kPa}$.

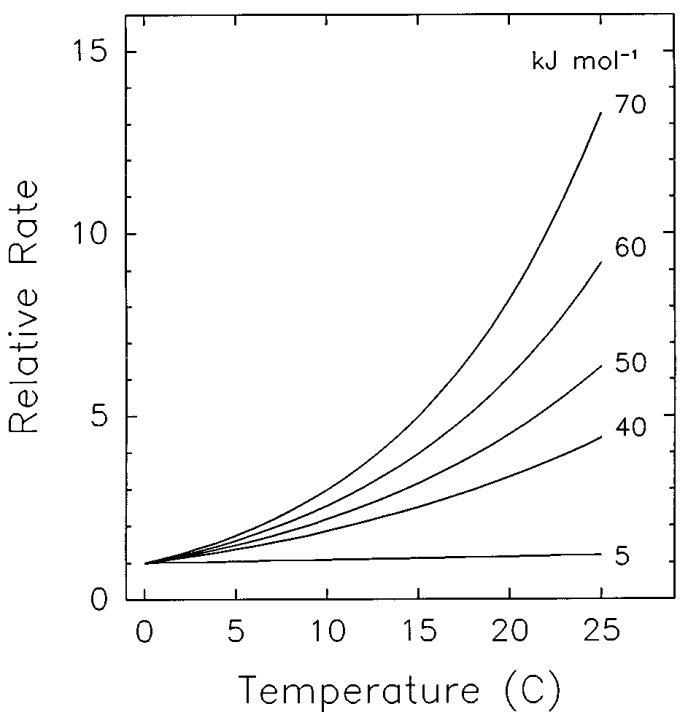

Fig. 5. Plots of relative rate vs. temperature for a range of activation energies. Data were generated using the Arrhenius equation before transformation to a relative rate of 1 at $0 \mathrm{C}$.

through pores (e.g., porous membrane), $\mathrm{E}_{\mathrm{a}}^{\mathrm{P}_{2}}$ would probably be similar to that for free diffusion (Nobel, 1983) which can be calculated as $\approx 4.3 \mathrm{~kJ} \cdot \mathrm{mol}^{-1}$. When $\mathrm{E}_{\mathrm{a}}^{\mathrm{P}_{2}}$ is fixed at $5 \mathrm{~kJ} \cdot \mathrm{mol}^{-1}$, the model predicts that even a small increase in temperature above $0 \mathrm{C}$ would cause a deleterious decrease in $\left[\mathrm{O}_{2}\right]_{\mathrm{pkg}}$ (Fig. 6). For a package using holes and optimized to $2 \mathrm{kPa}$ at $0 \mathrm{C},\left[\mathrm{O}_{2}\right]_{\mathrm{pkg}}$ was predicted to fall to $1 \mathrm{kPa}$ and less as the temperature increased to $\geq 5 \mathrm{C}$. Packages optimized to $4 \mathrm{kPa} \mathrm{O}_{2}$ at $25 \mathrm{C}$ using holes were predicted to reach steady-state $\mathrm{O}_{2}$ of nearly $17 \mathrm{kPa}$ at $0 \mathrm{C}$ (Fig. 7). A package made of a film with an $\mathrm{E}_{a}^{\mathrm{P}_{2}}$ of $50 \mathrm{~kJ} \cdot \mathrm{mol}^{-1}$ was predicted to maintain $\left[\mathrm{O}_{2}\right]_{\mathrm{pkg}}$ nearly constant at $4 \mathrm{kPa}$ over the range of temperatures from 0 to $25 \mathrm{C}$. The model predicts that an MA packet made of a film with a very high $\mathrm{E}_{\mathrm{a}}^{\mathrm{PO}_{2}}\left(\mathrm{e} . \mathrm{g} .,>70 \mathrm{~kJ} \cdot \mathrm{mol}^{-1}\right)$ optimized at $25 \mathrm{C}$ would become anaerobic at $0 \mathrm{C}$.

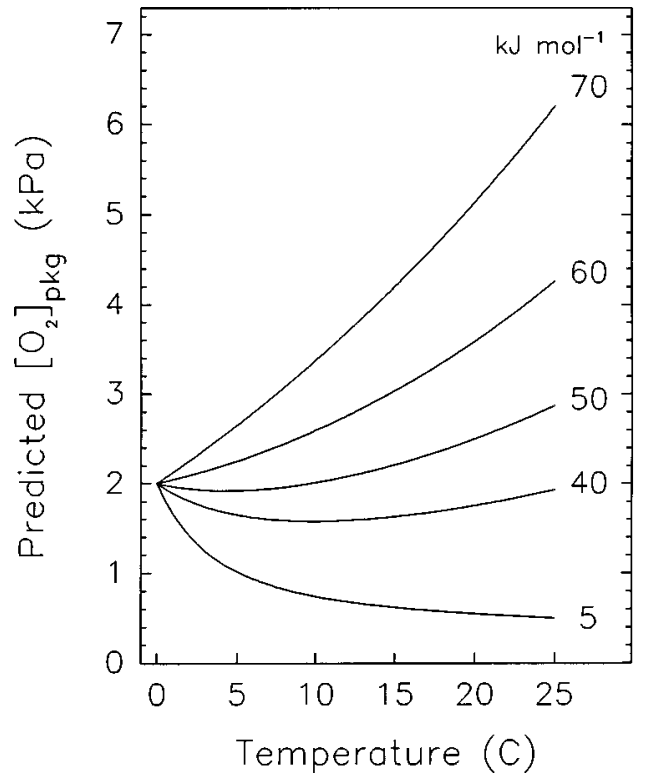

Fig. 6. Predicted $\left[\mathrm{O}_{2}\right]_{\mathrm{pgg}}$ changes in MA packages of blueberry fruit based on initial optimization to $2 \mathrm{kPa}$ at $0 \mathrm{C}$ (permeability data given in Table 3 ) for films with various values for $\mathrm{E}_{\mathrm{a}}^{\mathrm{P}_{2}}$. Predictions were generated using Eq. [7] with appropriate substitutions from Eqs. [3], [4], and [6]. Film permeability was assumed to respond to temperature in a standard Arrhenius function. 


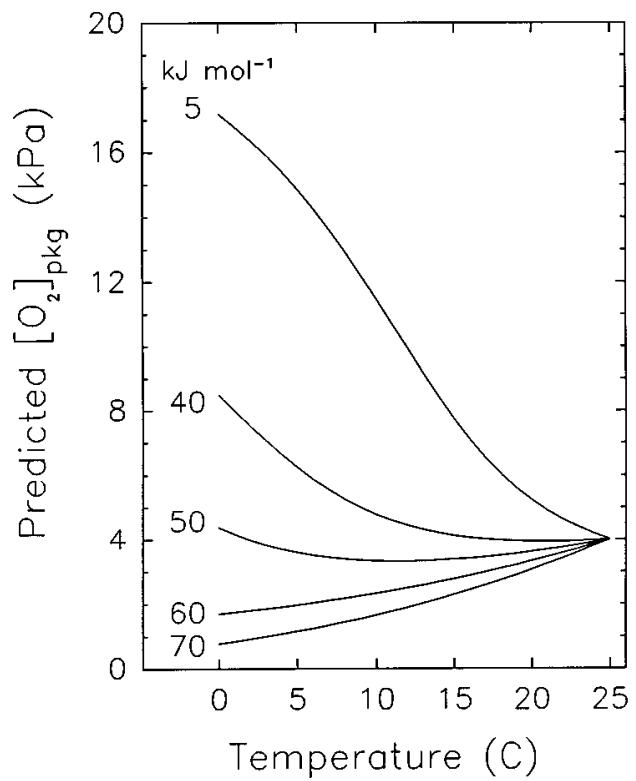

Fig. 7. Predicted $\left[\mathrm{O}_{2}\right]_{\mathrm{pkg}}$ changes in MA packages of blueberry fruit based on initial optimization to $4 \mathrm{kPa}$ at $25 \mathrm{C}$ (permeability data given in Table 3 ) for films with different values for $\mathrm{E}_{\mathrm{a}}^{\mathrm{P}_{2}}$. Predictions were generated using Eq. [7] with appropriate substitutions from Eqs. [3], [4], and [6]. Film permeability was assumed to respond to temperature in a standard Arrhenius function.

\section{Discussion}

There is considerable risk associated with MA package systems when attempts are made to reduce $\left[\mathrm{O}_{2}\right]_{\mathrm{pkg}}$ to effective levels at low temperatures because anaerobic conditions can develop if temperature increases during subsequent handling. Kader et al. (1989) proposed that this problem might be overcome by matching $\mathrm{E}_{a}^{\mathrm{P}_{2}}$ of the polymer film to that of fruit respiration. However, the activation energy for $\mathrm{O}_{2}$ uptake by blueberry fruit was found to be considerably larger than that of commonly used polymer films and was not constant with temperature or $\mathrm{O}_{2}$ partial pressure (Fig. 4). The proposal of Kader et al. (1989) is further confounded by the increase in fruit RQ breakpoint at elevated temperatures (Beaudry et al., 1992) and the associated loss of fruit quality. The changes in RQ breakpoint with temperature are thought to be related to the greater difference between $\left[\mathrm{O}_{2}\right]_{\mathrm{pkg}}$ and the $\mathrm{O}_{2}$ concentration in the fruit's internal atmosphere $\left(\left[\mathrm{O}_{2}\right]_{\mathrm{i}}\right)$ at elevated temperatures (Beaudry et al., 1992; Dadzie et al., 1992). Thus, simply matching the respective $E_{a} s$ is not sufficient to avoid the risk of anaerobiosis in MA-packaged blueberries at higher temperatures if the package is optimized to achieve benefits at low temperatures.

Our model predicts that a polymer film with an $\mathrm{E}_{a}^{\mathrm{P}_{2}}$ of $\approx 60$ $\mathrm{kJ} \cdot \mathrm{mol}^{-1}$ would maintain tolerable $\left[\mathrm{O}_{2}\right]_{\mathrm{pkg}}$ over a range of 0 to $25 \mathrm{C}$ (Fig. 7). A review of film permeability data (Pauly, 1989) indicates that there are few known polymer films with such a high $\mathrm{E}_{\mathrm{a}}^{\mathrm{P}_{2}}$; those polymers available tend to have low $\mathrm{P}_{\mathrm{O}_{2}}$. An inverse relationship between $\mathrm{P}_{\mathrm{i}}$ and $\mathrm{E}_{\mathrm{a}}^{\mathrm{P}_{\mathrm{i}}}$ seems to be a common feature of polymer films (Pauly, 1989). For instance, poly(vinyl chloride) and poly(vinylidene chloride) have suitably high values for $\mathrm{E}_{a}^{\mathrm{P}_{2}}$, but, to achieve suitable levels of permeability to $\mathrm{O}_{2}$, film thicknesses would have to be reduced by factors of $>50$ and 500 times, respectively, compared to polyethylene films. This presents a rather formidable challenge from a technical point of view, as such thin films $(0.01$ to $0.1 \mu \mathrm{m})$ would be unlikely to have adequate mechanical strength. It may be feasible to laminate such films onto a porous membrane or other suitable polymer for support. The lack of such films explains why empirical approaches to the tempera- ture problem have not been successful. Perhaps the best compromise with existing materials might be to use polypropylene films; these have a lower $\mathrm{E}_{\mathrm{a}}^{\mathrm{P}_{2}}$ than desired, but at least have adequate $\mathrm{P}_{\mathrm{O}}$. If a polypropylene-wrapped MA package of blueberries were optimized to maintain $\left[\mathrm{O}_{2}\right]_{\mathrm{pkg}}$ at $4 \mathrm{kPa}$ at $25 \mathrm{C}$, it would also contain $\approx 4 \mathrm{kPa} \mathrm{O}$ at $0 \mathrm{C}$ (Fig. 7). This is higher-than-optimum levels (Beaudry et al., 1992), but could still have some beneficial effect and would minimize the risk of anaerobiosis.

At least one commercial MA package is based on entry of $\mathrm{O}_{2}$ via small pores as a means to increase the permeability to $\mathrm{O}_{2}$. Although this technique has certain advantages (i.e., permitting higher partial pressures of $\mathrm{CO}_{2}$ ), it has the disadvantage that diffusion through holes is relatively temperature-independent. Perhaps one of the most important predictions of the model is that, even with a few-degree increase in temperature over $0 \mathrm{C}$, such packages would go anaerobic if allowed to attain steady-state (Fig. 6). Thus, essentially perfect temperature control would be required during handling and marketing if MA packages of this nature were optimized to $2 \mathrm{kPa} \mathrm{O}_{2}$ at $0 \mathrm{C}$. Presumably, commercial packages based on perforations are not optimized to such low levels of $\left[\mathrm{O}_{2}\right]_{\mathrm{pkg}}$ at $\mathrm{OC}$ because of the risk of temperature abuse during handling and retailing of the produce. However, data on $\mathrm{O}_{2}$ partial pressures are not readily available for commercial packages and, to our knowledge, this problem has not been previously discussed in the literature.

One advantage of perforation-limited diffusion in MA packages is that it results in a greater accumulation of $\mathrm{CO}_{2}$ relative to reduction of $\mathrm{O}_{2}$ compared to film-mediated diffusion. For instance, if $5 \mathrm{kPaCO}_{2}$ were shown to improve crop shelf life at $0 \mathrm{C}$, a package could be designed with perforations that would maintain this $\mathrm{CO}_{2}$ level; its $\left[\mathrm{O}_{2}\right]_{\mathrm{pkg}}$ would be $\approx 17 \mathrm{kPa}$ [the RQ of aerobic blueberries is $\approx 1.3$ (Beaudry et al., 1992)]. Such a package would have an $\left[\mathrm{O}_{2}\right]_{\mathrm{pkg}}$ of $\approx 4 \mathrm{kPa}$ at $25 \mathrm{C}$ and hence avoid anaerobiosis in the fruit (see Fig. 7). The corresponding concentration of $\mathrm{CO}_{2}$ at $25 \mathrm{C}$ would be $\approx 22 \mathrm{kPa}$, which may or may not be harmful to the fruit.

An alternative approach for avoiding risk of anaerobiosis in MA packages transferred to high temperatures has been proposed by Patterson and Cameron (1992). In this case, an MA package can be optimized to a given $\left[\mathrm{O}_{2}\right]_{\mathrm{pkg}}$ at $0 \mathrm{C}$ or any other appropriate temperature. If the package is inadvertently exposed to an elevated temperature during handling or marketing, it actively responds by opening holes, thereby augmenting overall package permeability. Aerobic conditions can be maintained during temperature abuse, even when polymers such as LDPE are used, because the active portion of the package can be inserted as a small window in the film. Packages that respond actively either to environmental changes or to volatile signals from the packaged product may prove to be useful for overcoming some of the current limitations of passive MA.

The $\mathrm{Q}_{10}$ of 3.2 for blueberry $\mathrm{R}_{\mathrm{O}_{2}}^{\text {max,T }}$ was about the same as those calculated for other soft fruits from data published by Hardenburg et al. (1986). The fact that $\mathrm{R}_{\mathrm{O}_{2}}$ at $25 \mathrm{C}$ appears to be substantially limited by $\left[\mathrm{O}_{2}\right]_{\mathrm{pkg}}$, even at $16 \mathrm{kPa}$, suggests that blueberries have a high skin resistance to gas diffusion. This fact may also explain why $\mathrm{E}_{\mathrm{a}}^{\mathrm{R}_{2}}$ appears to change with both $\left[\mathrm{O}_{2}\right]_{\mathrm{pkg}}$ and temperature (Fig. 4), as well as the temperature dependence of $\mathrm{K}_{1 / 2} . \mathrm{R}_{\mathrm{O}_{2}}$ is expected to be a function of $\left[\mathrm{O}_{2}\right]$ inside the fruit, which, in turn, would be a function of skin resistance to gas diffusion, $\mathrm{R}_{\mathrm{O}}$ and $\left[\mathrm{O}_{2}\right]_{\mathrm{pkg}}$. At low levels of $\left[\mathrm{O}_{2}\right]_{\mathrm{pkg}}$, small changes in $\left[\mathrm{O}_{2}\right]$ had relatively large effects on the rate of $\mathrm{O}_{2}$ uptake (Fig. 3); thus similar differences between internal and external atmosphere composition could strongly influence the prediction of $\mathrm{E}_{\mathrm{a}}^{\mathrm{R}_{2}}$ for a given level of $\left[\mathrm{O}_{2}\right]_{\mathrm{pkg}}$. The observation that 
calculated $\mathrm{E}_{\mathrm{a}}^{\mathrm{R}_{2}}$ was least temperature-dependent at the highest level of $\left[\mathrm{O}_{2}\right]_{\mathrm{pkg}}$ is consistent with this interpretation. A further complication is the possibility that skin resistance to $\mathrm{O}_{2}$ diffusion in blueberries is itself affected by temperature (Dostal-Lange et al., 1991). Clearly, it would ultimately be desirable to model $R_{\mathrm{O}_{2}}$ as a function of internal $\left[\mathrm{O}_{2}\right]$, but the number of unknowns prevented this approach from being adopted in this study.

We have demonstrated that there are some consistent and useful relationships that can be used to explore the feasibility of different approaches to MA packaging for blueberries and we believe that these concepts may have general applicability for other crops. However, the extent to which between-fruit and between-group variation may affect crop response to a given packaging treatment has yet to be characterized; what works for one group of fruit may not always work for another. The blueberry experiment reported by Beaudry et al. (1992) was repeated the following season with very similar results, except that the RQ breakpoint at $25 \mathrm{C}$ was $\approx 5$ $\mathrm{kPa} \mathrm{O}_{2}$ rather than $4 \mathrm{kPa}$ (Beaudry et al., unpublished data). However, there is clearly still scope for variability in this type of system. For example, it probably would be too dangerous to optimize packages down to 2 and $4 \mathrm{kPa} \mathrm{O}_{2}$ at 0 and $25 \mathrm{C}$, respectively, because of the risk of some of the packages becoming anaerobic. The variability in response of a given crop type to a particular package configuration is one of the critical issues that requires careful investigation before MA packaging can become a dependable technology, especially because it may explain why few commercial MA systems are marketed currently.

\section{Literature Cited}

Banks, N.H., E.W. Hewett, N.C. Rajapakse, D.J. Cleland, P.C. Austin, and T.M. Stewart. 1989. Modeling fruit response to modified atmospheres, $\mathrm{p}$. 359-366. In: J.K. Fellman (ed.). Proc. Fifth Intl. Controlled Atmosphere Res. Conf. Vol. 1. Pome fruits. 14-16 June, Wenatchee, Wash.

Beaudry, R.M., A.C. Cameron, A. Shirazi, and D.L. Dostal-Lange, 1992. Modified-atmosphere packaging of blueberry fruit: Effect of temperature on package $\mathrm{O}_{2}$ and $\mathrm{CO}_{2}$. J. Amer. Soc. Hort. Sci. 117:436-441.
Cameron, A.C., W. Boylan-Pett, and J. Lee. 1989. Design of modified atmosphere packaging systems: Modeling oxygen concentrations within sealed packages of tomato fruits. J. Food Sci. 54:1413-1416, 1421.

Dadzie, B.K., N.H. Banks, D.J. Cleland, and E.W. Hewett. 1993. Role of skin resistance to gas diffusion in the response of fruits to modified atmospheres. Acta Hort. 343:129-134.

Dostal-Lange, D., R.M. Beaudry, A. Shirazi, and A.C. Cameron. 1991. Modified atmosphere packaging of blueberries: Effects of temperature and internal oxygen concentration onrespiration rate. HortScience 26:86. (Abstr.)

Emond, J.P., F. Castaigne, C.J. Toupin, and D. Desilets. 1991. Mathematical modeling of gas exchange in modified atmosphere packaging. Trans. Amer. Soc. Agr. Eng. 34:239-245.

Hardenburg, R.E., A.E. Watada, and C.Y. Wang. 1986. The commercial storage of fruits, vegetables, and florist and nursery stocks. rev. ed. USDA Hdbk. 66.

Kader, A.A., D. Zagory, and E.L. Kerbel. 1989. Modified atmosphere packaging of fruits and vegetables. Crit. Rev. Food Sci. Nutr. 28:1-30.

Kok, R. and G.S.V.Raghavan. 1985. A mathematical model of a Marcellin type storage system. Acta Hort. 157:31-40.

Lee, D.S., P.E. Haggar, J. Lee, and K.L. Yam. 1991. Model for fresh produce respiration in modified atmospheres based on the principles of enzyme kinetics. J. Food Sci. 56:1580-1585.

Mannapperuma, J.D., D. Zagory, and A.A. Kader. 1989. Design of polymeric packages for modified atmosphere storage of fresh produce, p. 225-233. In: J.K. Fellman (ed.). Proc. Fifth Intl.Controlled Atmosphere Res. Conf. Vol. 2. Other commodities and storage recommendations. 14-16 June, Wenatchee, Wash.

Nobel, P.S. 1983. Biophysical plant physiology and ecology. Freeman, New York.

Patterson B.D. and A.C. Cameron. 1992. Modified atmosphere packaging. Intl. Patent no. PCT/AU90/00267.

Pauly, S. 1989. Permeability and diffusion data. Polymer handbook. vol. 4. 3rd ed. Wiley, New York. p. 435-449.

Smittle, D.A. and W.R. Miller. 1988. Rabbiteye blueberry storage life and fruit quality in controlled atmospheres and air storage. J. Amer. Soc. Hort. Sci. 113:723-728.

Wade, N.L. and Graham, D. 1987. A model to describe the modified atmospheres developed during the storage of fruit in plastic films. ASEAN Food J. 3:105-111. 